\title{
Building the Modernist rural landscape in the Salazar's Regime: The agricultural colony of Boalhosa
}

\author{
Paolo Marcolin ${ }^{2,1}$, Joaquim Flores ${ }^{2}$, and Isabel Matias ${ }^{2}$ \\ ${ }^{2}$ CEAA/ESAP, Centro de Estudos Arnaldo Araújo/ESAP, Porto, Portugal.
}

\begin{abstract}
The construction of the modernist rural landscape in Portugal bears the mark of the Junta de Colonização Interna, an institution created in 1936 during the Salazar regime within the Ministry of Agriculture. The colonies which were actually completed and whose original structures remain until today are regarded as singular experiences that, having assumed the assumptions of modernity, have sought to establish continuity with certain aspects of landscape and vernacular architecture. This research aims to test the methodology proposed for the analysis of the physical legacies of these colonies, applying it on the Agricultural Colony of Boalhosa. The methodology combines GIS and mapping analysis, covering several layers of information embarking natural and anthropogenic spatial data, which allow understanding the landscape transformation since the settlement of the colony. From the reading of the landscape structure of this colony, it was verified that these legacies were accomplished through the use of an autonomous design methodology, which considers the local culture and respects both the morphological and physiographic characteristics of the existing site, leading to the creation of modern landscapes strongly tied to the local identities.
\end{abstract}

\section{Introduction: the general process of internal colonization}

The construction of the modernist rural landscape in Portugal is marked by the Junta de Colonização Interna $(\mathrm{JCl})$, an institution created in 1936 during the Salazar regime within the Ministry of Agriculture. Together with the development of agricultural hydraulics and forest settlement, the internal colonization was one of the main objectives of the regime for the agricultural sector [1]. Between the 1930s and the 1940 s, several studies were carried out to identify and characterize the baldios, vacant common land aimed for internal colonization, and the colonization projects of the "first" internal colonization project were designed [2]. The projects of the "second" internal colonization project coincide with the beginning of the $2^{\text {nd }}$ Development Plan [2] and were conceived and implemented in the 1950s and 1960s.

Unlike the projects of the first phase, which were strongly concerned with the ideological issues, these projects aimed to turn colonization into an instrument to

\footnotetext{
${ }^{1}$ Corresponding author: arqmarcolin@gmail.com
} 
enlarge the internal market through the establishment of economically viable agricultural companies [3]. Furthermore, these projects would enable a colonization model suitable for the expansion of the industrial agriculture, thus contributing for the application in Portugal of the "green revolution" solutions which were transforming the rural territories in the nearby countries [4]. Additionally, it was expected that such projects could turn into a spreading focus of the technological innovations that would contribute to improve the practices of conventional farmers [3]. For the internal colonization the regime allocated the communal forest land (baldios), aiming its partial transformation for agricultural use through the improvement of soils and the introduction of pioneer forest species that would help to produce fertile soil. The limitations imposed by the Regime to the $\mathrm{JCl}$ will ultimately compromise the overall result of the colonization.

The colonies whose original structures remain until today are considered as relatively singular experiences that, having assumed the presuppositions of modernity, try also to establish the continuity with the landscape and with the vernacular architecture. This demand is particularly visible in the territories of Minho and Trás-osMontes. Here, the capacity to interpret the site and its topography is mediated by the careful elaboration of agricultural landscape plans in articulation with the settlement's projects. This is also one of the main criteria for choosing the Boalhosa Colony as an exemplary case for the first application of the methodology of analysis and study of the modernist landscape in Portugal.

\section{Planning and construction of the landscape during the regime period}

\section{The colonization project}

The first study for the Boalhosa Colony in the Alto Minho region was carried out in 1939 [5], year in which began the identification of the continent's baldios. The study predicted the use of the vacant common land located in the Serra da Boalhosa, which, by being located contiguously, formed a spatial continuity of circa twelve kilometres in length, encompassing the municipalities of Paredes de Coura, Monção and Arcos de Valdevez. The plan included also the establishment of three settlements, the first of which, Chã do Real, to be located in the central zone, and the other two, Chã das Pipas and Chã de Lamas, respectively in the North and South zones.

Seven years later, in 1946, following the "General plan for the use of the reserved baldios" [6], the Colonization Project is elaborated for an area of 1150 hectares, proposing a fourth settlement, Concessão, as well as the construction of 83 casais [agricultural plots with individual houses] and several public buildings to give technical, medical and social support to the four settlements [7]. In 1951, after a new assessment of the characteristics and conditions of the baldios by the $\mathrm{JCl}$ technicians, which leaded to the reduction of the area effectively available for colonization to circa 680 hectares, a new colonization project was elaborated which, although maintaining the four planned settlements, reduces the number of casais from 83 to 68 [8]. Three years later, in 1954, the project was executed only in the Vascões - Chã de Lamas settlement, where 30 casais were set up in 15 semi-detached houses.

\section{Settlement model and design}

The Boalhosa settlement adopted the "concentrated" model [9], and follows a strategy which gave preference to group solutions, considered more advantageous both for the 
use and location of the farming land, and for the greater proximity to the collective services and facilities. The Lobo and Antunes' study, which argued that in rural areas the house grouping should be preferential in order to mitigate a series of deficiencies consequent of the buildings isolation and the lack of basic infrastructure and collective facilities [10], was subsequently validated following the completion of the $\mathrm{JCl}$ projects. By adopting this type of solution, the colony's agricultural casais were compose by several plots organized in order to form more compact neighbourhoods, however not in the same way as population clusters or urbanized settlements with adequate infrastructure and collective facilities. The configuration of the settlements has, however, a certain urban complexity which seems influenced by models originated in the garden city and the design of its structure is organized in order to define a spatial system constituted by streets and square, in order to reinforce the unity of the settlement and promote a community environment.

From the analysis of the supporting texts of the urban and architectural projects of the Colony of Boalhosa, we verified, however, that there is no direct reference to foreign models. The only reference that associates the colonies settlements' model with the garden city was found in the Aldeia Nova do Barroso projects: "By this way we reduce the danger of fire considerably, with the advantage of giving to the whole the general appearance of a garden village, rather than a simple huddle of uninteresting houses." [11]. Nevertheless, it seems consensual in the bibliographical references found on this subject (Fernandes [12], Ramos [13], Rapazote [14]; Guerreiro [15]) the idea that the settlements are related with the model of the garden city, as well as the fact that there are a set of aspects that seem to relate the Portuguese colonies settlements with it, including the use of an organic design adapted to the topography.

Not excluding the possibility that certain international references may have served as an example or influenced some aspects of their urban and architectural design, it seems to us, however, that in the specific case of the Boalhosa colony other factors were more determinant. One is the meticulous observation of the place by the designers, who spent several days camped there to better understand their natural conditions and qualities, which also explains the careful geographical location of the settlement [15]. Another is the reading and interpretation of the spatial and architectural references existing in the region, in order to find a design and scale suited to the settlement's size, as well as an architectural expression resulting from the articulation of the modernist principles with the regional specificity, revealing signs of modernism and a certain proximity to the critical regionalism of the fifties. Within this logic it can be observed that the location of the streets and buildings follows directly the contour lines, thus taking full advantage of the topographic conditions, minimizing the earthworks and conserving the natural landscape morphology. By taking advantage of the steep slope of the terrain it was still possible to open the living area towards the south-facing valley. Following this site planning the houses were organized in a semi-detached configuration, including barns and stables, thus guaranteeing both the rational distribution of spaces and the social and architectural representation of each building.

\section{Agricultural landscape planning}

The planning of the Boalhosa Colony agricultural landscape resulted from soil studies and two agricultural exploitation plans, but ended up being executed only in the Vascões settlement. The first agricultural land "Exploitation Plan" was elaborated and integrated in the 1946's "Colonization Project". This plan was based on studies aimed at identifying the soil properties (agrological, hydrological and agricultural capability) and on ensuring 
the self-sufficiency of the agricultural casais [7]. With the exception of the low fertility land, for which the woods had been planned, the plan identified the best land for the cereal crops (mainly maize, potatoes and rye) associated with other forage crops for the maintenance of cattle and shrubs for the production of natural fertilizers [7]. The execution of this plan began in 1955, with the elaboration of a working plan to transform and infrastructure the Vascões settlement land [16]. The second plan dates back to 1964, and results from the same year "Revision of the Boalhosa Centre colonization plan". This revision follows the recognition of situations that required the rethinking of the colonization project size, as well as the orientation of the agricultural exploitation of the casais. On the one hand, after having verified that the land area did not corresponded to those identified in the 1946 plan and following a court decision ordering the reintegration of several plots into the private domain, it re-adjusted the colony by reducing the number of casais originally planned [17]. On the other hand, it redefined the previous exploitation plan following a new agrological study, which showed that the casais agricultural exploitation should be farm-oriented, since the land with a high capacity and profitability for cereal crops was low [18].

\section{Landscape structure in the current context}

\section{Methodology}

Considering the Colony a paradigmatic case in the construction of the Portuguese Modernist Rural Landscape, it is justified the application of an analysis methodology capable of assessing and understanding the impact and importance of the physical legacies as an emerging landscape and cultural heritage. On the other hand, considering that this methodology will also be used to analyze other agricultural colonies promoted by the $\mathrm{JCl}$ during the Salazar's regime, it was used a model capable of embarking different realities, which was previously developed within the MODSCAPES project to study the physical legacies. Furthermore, it was important to use a method which could lead to understand how the landscape was before and after the colonization, what phases characterized the process of planning and construction of the colony in different spatial scales, as well as the reasons that contributed to the conservation or transformation of its legacies.

The landscape definition expressed in the European Landscape Convention - "an area as perceived by people, whose character is the result of natural and/or human processes" [19], was the beginning to identify the structural nature of the built environment and to understand the relationship between the structure of the settlements and the characteristics of the physical support. The Convention's definition suggests that in order to analyze the landscape evolution over a relatively short period of time, three aspects must be considered: the structure, relative to physical and biophysical patterns and components of the colony and its landscape; the image, linked to the perception of the landscape and its sensorial impact; and action, which refers to the human actions that shaped the colony's landscape. This model allows crossing a series of information and results in order to obtain a holistic, integrated and complete image of the landscape and its evolution process [20]. In this sense, the landscape is identified and analyzed by layers that range from natural geology to human activities, including their transformation.

It is also worth mentioning that the landscape characterization of the Boalhosa colony territory follows the criteria adopted in the Terras de Coura Landscape Plan [21], on which the landscape subunits multifunctional analysis is based on the methodology 
provided in the document of the Direção Geral do Ordenamento do Território e Desenvolvimento Urbano - DGOTDU [22], as well as on several national and international studies, including the works of Cancela d'Abreu [23], Pinto-Correia [24] and De Groot [25]. As a result, the territory of the colony was partially included in NATURA 2000 and entirely in the landscape sub-unit of Monte da Boalhosa - Planalto de Lamas. The structure is thus evaluated by reading plans or thematic maps, from the oldest to the most recent, according to the historical GIS method [26]. The maps are analyzed through their graphic representations, comparing the programmed and produced landscapes with the current one. The working methodology aims to combine several data of the landscape territorial evolution, since it compares the starting situation with the contemporary one, allowing analyzing the long term landscape change. However, as the work is still under development, in the next few points will be presented only a synthesis of the results and conclusions obtained from the landscape structure analysis performed.

\begin{tabular}{|c|c|c|c|}
\hline \begin{tabular}{|l|} 
Subject \\
\end{tabular} & \begin{tabular}{|l|} 
GIS feature \\
\end{tabular} & \begin{tabular}{|l} 
Topology \\
\end{tabular} & \begin{tabular}{|l|} 
Attributes \\
\end{tabular} \\
\hline \multirow{22}{*}{ Landscape / Infrastructures } & \multirow{3}{*}{ terrain countour line } & \multirow{3}{*}{ line } & \begin{tabular}{|l|} 
elevation \\
\end{tabular} \\
\hline & & & date \\
\hline & & & \begin{tabular}{|l|} 
source \\
\end{tabular} \\
\hline & \multirow{2}{*}{ terrain elevation points } & \multirow[b]{2}{*}{ points } & \begin{tabular}{|l|} 
elevation \\
\end{tabular} \\
\hline & & & \begin{tabular}{|l|l|} 
date \\
\end{tabular} \\
\hline & river & ling & \begin{tabular}{|l} 
source \\
name \\
\end{tabular} \\
\hline & \begin{tabular}{|l} 
canal \\
\end{tabular} & \begin{tabular}{|l} 
line \\
\end{tabular} & \begin{tabular}{|l} 
name \\
name \\
\end{tabular} \\
\hline & \multirow{3}{*}{ irrigation canal } & \multirow{3}{*}{ line } & name \\
\hline & & & type \\
\hline & & & date of construction \\
\hline & \multirow[b]{2}{*}{ roads } & \multirow[b]{2}{*}{ line } & name \\
\hline & & & type \\
\hline & \multirow{3}{*}{ rails } & \multirow{3}{*}{ line } & \begin{tabular}{|l} 
date of construction \\
name
\end{tabular} \\
\hline & & & \begin{tabular}{|l|l} 
type \\
\end{tabular} \\
\hline & & & date of construction \\
\hline & \multirow{2}{*}{ Original land use } & \multirow{2}{*}{ polygon } & \begin{tabular}{|l|} 
original use \\
\end{tabular} \\
\hline & & & \begin{tabular}{|l|} 
date \\
\end{tabular} \\
\hline & \multirow{2}{*}{ Project land use } & \multirow{2}{*}{ polygon } & \begin{tabular}{|l|} 
project use \\
\end{tabular} \\
\hline & & & \begin{tabular}{|l|} 
date \\
\end{tabular} \\
\hline & \begin{tabular}{|l} 
Current land use \\
\end{tabular} & polygon & \begin{tabular}{|l|} 
current use \\
\end{tabular} \\
\hline & \begin{tabular}{|l} 
Land suitability study \\
\end{tabular} & polygon & Land suitability \\
\hline & Landscape type & \begin{tabular}{|l|l|} 
polygon \\
\end{tabular} & Landscape type \\
\hline \multirow{18}{*}{ Colony / Settlement } & \multirow{5}{*}{ Parcels } & \multirow{5}{*}{ polygon } & \begin{tabular}{|l|l|} 
name \\
\end{tabular} \\
\hline & & & \begin{tabular}{|l|} 
original owner \\
\end{tabular} \\
\hline & & & \begin{tabular}{|l|} 
owner \\
\end{tabular} \\
\hline & & & \begin{tabular}{|l} 
project area \\
\end{tabular} \\
\hline & & & \begin{tabular}{|l} 
current area \\
\end{tabular} \\
\hline & \multirow{13}{*}{ Building } & \multirow{13}{*}{ Polygon } & name \\
\hline & & & built \\
\hline & & & date of construction \\
\hline & & & \begin{tabular}{|l} 
level of integrity \\
\end{tabular} \\
\hline & & & date of modification 1 \\
\hline & & & \begin{tabular}{|l} 
modification 1 \\
\end{tabular} \\
\hline & & & \begin{tabular}{|l|} 
project area \\
\end{tabular} \\
\hline & & & \begin{tabular}{|l} 
current area \\
\end{tabular} \\
\hline & & & \begin{tabular}{|l|} 
height \\
number of floors \\
\end{tabular} \\
\hline & & & state of conservation \\
\hline & & & $\begin{array}{l}\text { families } \\
\end{array}$ \\
\hline & & & residents \\
\hline & & & type of residents \\
\hline \multirow{2}{*}{ Administrative } & \multirow{3}{*}{$\begin{array}{l}\text { Administrative boundaries } \\
\text { Census data }\end{array}$} & \multirow{2}{*}{ polygon } & name \\
\hline & & & \begin{tabular}{|l|} 
level \\
\end{tabular} \\
\hline Demographics & & polygon & all the official census \\
\hline
\end{tabular}

Fig. 1. Geographic Information System (GIS) Layers structure

\section{Structure: components and transformations}

\section{Components}

The Boalhosa Colony is still today a paradigmatic case, not only because it represents an exemplary way of reinventing the rural landscape, but also because it was located in an area with natural and landscape exceptional values. It was not coincidence that in 1999, circa forty years after the colony was completed and the first settlers arrived, part of its agricultural and forestry areas were included in the Corno do Bico Protected Landscape, whose conservation statute was attributed due to its ecological and landscape quality and by the presence of habitats that provide shelter to various protected species of fauna and flora [27]. 


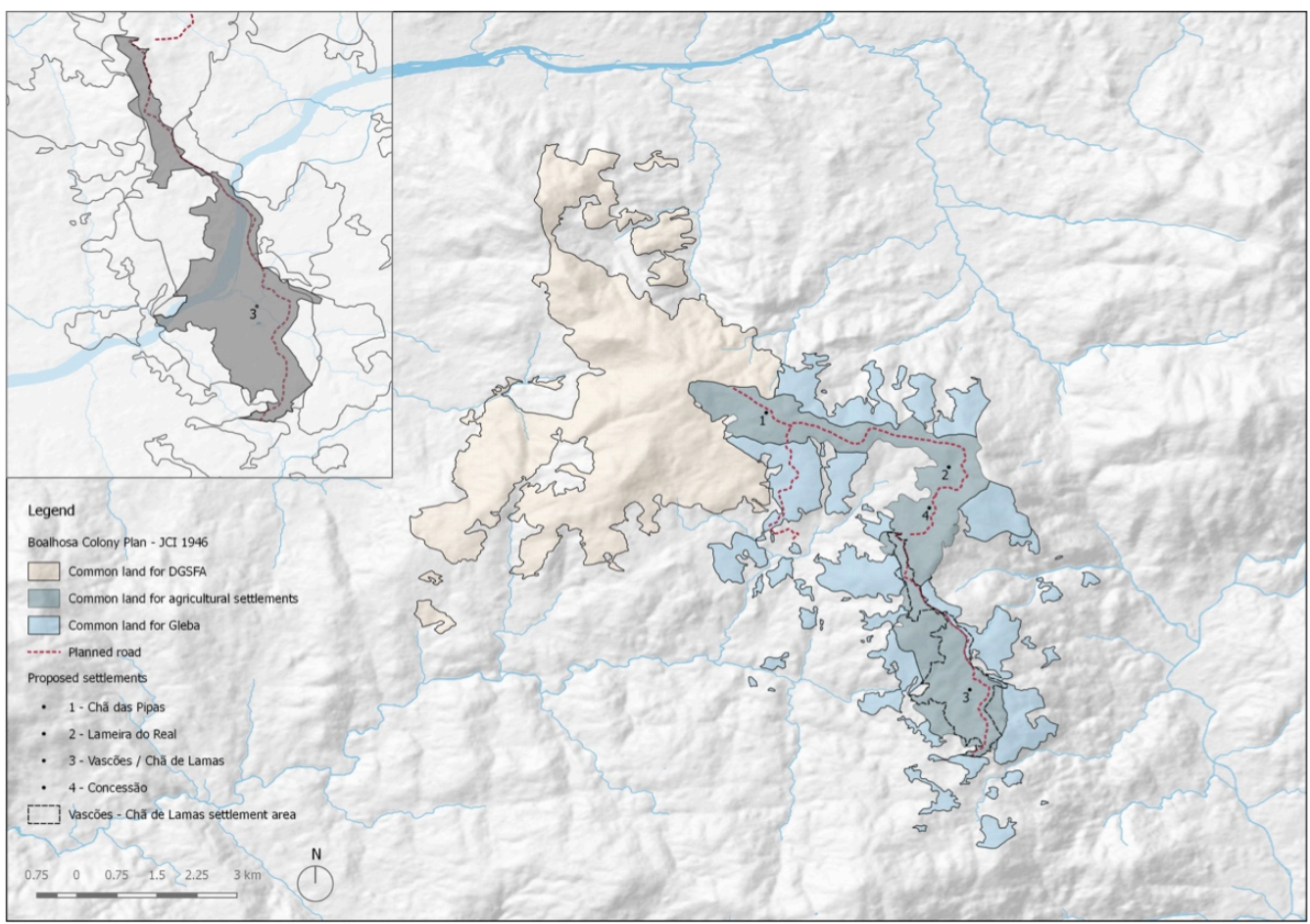

Fig. 2. Boalhosa Colony Plan. JCI 1946 (GIS mapping)

Currently, the Vascões settlement remains independent from the main access roads and somewhat distant from the places and towns located in its widened surroundings, which gives it a prominent image and a strong formal unity. This unit derives from the aforementioned concentrated model and the guidelines used for planning the settlement, namely the axis that defines the symmetrical configuration of the urban structure, designed in order to follow the orientation of the natural slope of the terrain and the Monte de Lamas ridge line, which constitutes a geomorphological unit embarking a flattened top and an intermediate slope area [21]. The components (abiotic, biotic and cultural) that currently characterize the landscape structure of the Vascões settlement remains identical to those that existed when the settlement was established.

Most of the abiotic component consists of metamorphic rocks (shale), being the remaining eruptive rocks (granites). The way this component developed leaded to a rather heterogeneous relief [21] where sloping areas (varying from accentuated to medium or soft) and top and bottom flattened areas alternate. Consequently the hydrographic network is dense and there is a generalized abundance of water, which is also reinforced by rainfall, being this one of the most significant and constant climatological factors of the region [21]

The agricultural and forest production areas cover most of the colony's surface, and together with the listed areas of the protected landscape (Bushes and Agroforestry Mosaic) [21], contribute to determine the structural pattern of the colony's landscape. To these components associate the allotment of agricultural land and the agricultural irrigation infrastructure. The Vascões settlement, with its housing and communal facilities, the roads and the connecting paths between neighboring places, define the most obvious cultural components of the landscape. These components also comprise some prehistorical remains, the subtumuli monuments, which are marks of the space appropriation by the human groups that lived between the third and second millennium B.C. [21]. 


\section{Transformations}

According to the information collected and systematized through the GIS, it was possible to identify and organize the transformations in two categories: structural (Landscape/Infrastructure) and localized (Colony/Settlement), with a degree of coverage and incidence which changes accordingly to the period in which these occurred.

Thus, the structural transformations were associated with changes in the natural base components of the landscape and the land use, as well as to the land, irrigation, road and forest infrastructure improvement operations in the Baldios. These operations allowed to structure the colony's territory and to adapt certain components or elements of the preexisting landscape to the farming model envisaged in the colonization project, thus providing a modern and more efficient rural environment in terms of the agricultural production. Regarding the localized transformations, they are related with the colony's settlement and its built elements location, namely housing, community building and public spaces, all placed in a single site accordingly with the concentrated settlement model. In this category are also included the changes in the built elements occurred after its initial construction.

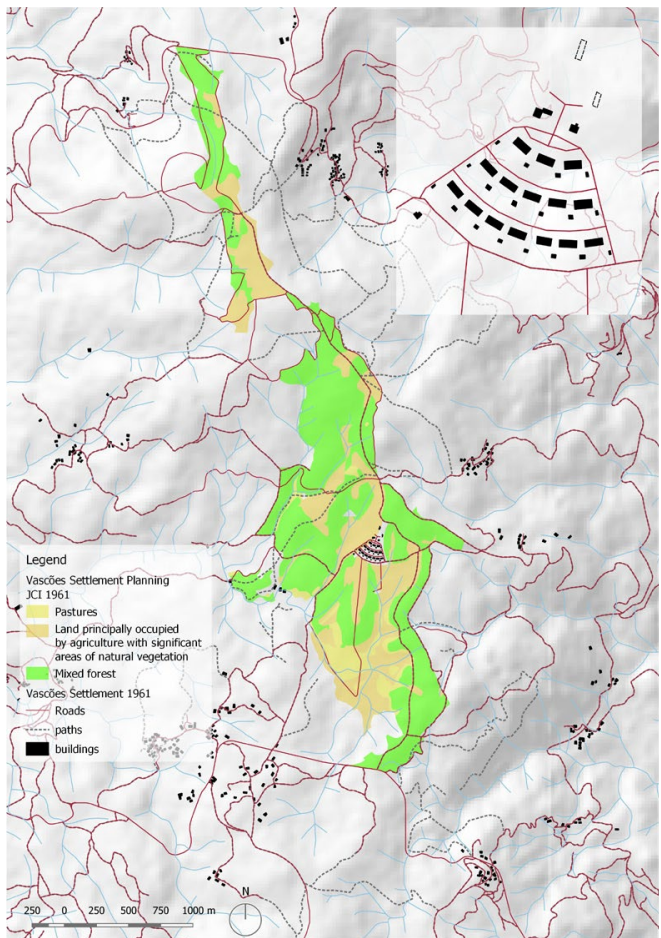

Figs. 3a and b. Vascões Settlement in 1961

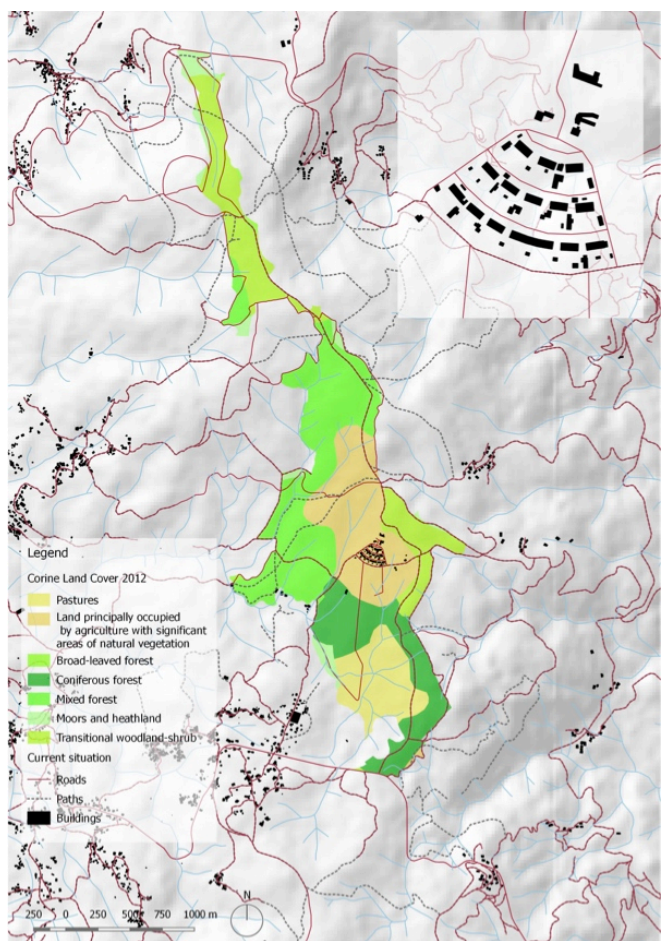

(a) and 2017 (b) (with Corine Land Cover 2012).

From the analysis carried out, it was verified that the most significant transformations of the pre-existing landscape occurred during the period in which the colony was planned and constructed, between 1946 and 1966, focusing essentially on the Vascões Settlement. The transformations occurred after 1966 up to the present time were very localized and lesser expressive in the agricultural and forestry landscape planning, although significant in the function changes and extension of the community buildings and of some houses. Before the execution of the works foreseen in the 1946's Colonization Project and in the 1964's Revision of the colonization plan of the Boalhosa Centre the pre-existing landscape was characterized essentially by the presence of 
pastures and woods, accessible only by rural paths. This configuration is confirmed not only by the information obtained from the 1940's military cartography, but also by the descriptions in the 1946 project, where it is stated that the territory of the Boalhosa Colony was characterized by "vast soft sloping surfaces where there are good plots of land, commonly called chãs or lameiros, with water all year and where there is a rich and varied spontaneous vegetation that gives good pasture" [7]. This landscape type developed not only due to the orographic characteristics, but also to the climatic conditions, being the territory of the colony "placed in an area of very high rainfall" [7].

In the 1960s, after the execution of the Vascões Settlement, the landscape became humanized and with elements and infrastructures in order to prepare it for a business exploitation, and which eventually assumed as identity and readability factors of the new productive landscape [15]. Between the 1950s and 1960s the primary improvement works were completed, including various transformation operations, such as the drainage of soils, the protection of the soil subjected to erosion processes, the introduction of tree curtains, the road and path construction for local accessibility and the execution of agricultural irrigation infrastructures (dams, wells, waterways, drainage ditches). From the mid-1960s onwards, and even after the colony had ceased to function, the transformations that took place were small, and did not reach an expression similar to the previous period. Although the lands became later property of the settlers, the structure of the property managed to remain practically unchanged until today. Similarly, the agricultural system, which never provided the economic income initially expected, mainly due to the climatic conditions, remained linked to local scale production.

It is possible to say that in general, in this second period, the landscape was able to conserve the character acquired with the construction of the settlements and of the necessary infrastructures for maintain the settlers and for the agricultural and forestry use of the baldios. Nevertheless it starts to appear in some lands a forest with nonautochthonous fast-growing species, such as eucalyptus, which in significant extensions can very quickly alter or compromise the ecosystem and the landscape pattern. The transformations thus focused mainly on the built elements of the Vascões settlement, and were fundamental to ensure the active permanence of the built physical legacies. Some houses were restructured and used as second homes. Although in some cases the intervention criteria applied has not able to ensure the full respect for the pre-existing architectural characteristics, the overall morphological result retains the distinctive features of the initial project.

Concerning the pre-existing community buildings, the School and the Teacher's House acquired new functions and became part of a new educational complex, the Center for Environmental Education and Interpretation of the Corno do Bico Protected Landscape. This structure, which is located on the same place where the unbuilt Chapel was planned, is intended to carry out research and environmental education activities, aiming to give notice about the specificities and values of the Corno do Bico Protected Landscape. Although partially, the introduction of this complex contributed to the revitalization of the settlement and to establish a new living experience for the local population encouraging the permanence of the inhabitants and the use of the landscape for recreation and leisure.

\section{Conclusions}

From the results of the landscape structure analysis the following conclusions were drawn: 
- The methodology used was applied to a case study in which the model is concentrated and the landscape structure (modernist) did not undergo radical changes, which turned easier the analysis of the landscape evolution and transformations. However, considering that in several $\mathrm{JCl}$ colonies the settlement patterns and transformations occurred have different characteristics from those of Boalhosa, this methodology may be adapted, while maintaining its basic principles and procedures, indispensable for an evolutionary understanding of the landscape.

- The political idea that promoted and sustained the agrarian reform ideology contributed to a rural landscape deeply marked by the values promoted by the Salazar's regime: identity, rurality and order [15]. This idea was materialized through the use of an autonomous project methodology, which accounted with local culture and tradition and respected the morphological and physiographic characteristics of the place, leading to the construction of a modern landscape with a strong connection to local identities. This seems to be one of the reasons why the physical legacies of the rural settlements and surrounding landscape remained almost unchanged, despite the extinction of the colony in the late 1980 s as a structure for the management of local agricultural production.

- Other reasons which have contributed to limit the transformation of the modernist rural landscape seem to be linked, on the one hand, to the agricultural productivity and economic profitability, which have proved to be much lower than those foreseen in the exploitation plans and did not encourage further investment in terms of the colony's expansion. On the other hand, the fact that a large part of the land of the colony and its extended surroundings were included in an area listed as a protected landscape, thus being subject to special protection which, together with the municipal planning guidelines, contributed to limit the transformation of the landscape.

- Considering the state of conservation of the colony's settlement, as well as the landscape and natural potential of the site, the classification and valorization of physical legacies can contribute not only to an agriculture of excellence, but also to develop activities in the field of environmental conservation and nature tourism.

\section{Acknowledgements}

This work was conducted under the project MODSCAPES - Modernist Reinventions of the Rural Landscape (HERA.15.097). This project has received funding from the European Union's Horizon 2020 research and innovation programme under grant agreement No 649307. the authors are grateful for the work of Joana Couto, Modscapes research fellow at CEAA.

\section{Short resumes}

Paolo Marcolin. Architect (Polytechnic of Milan), Master and PhD in Urban Project and Planning (Faculties of Architecture and Engineering of Oporto University). He is professor at ESAP since 2000. Marcolin has been developing research in urban and landscape areas. He is an affiliated researcher at Arnaldo Araújo Research Centre (FCT R\&D unit 4041) and at Laboratory of Research in Architecture and Design (LIAF/ESAP). He also is a collaborator researcher at Laboratory of Landscapes, Heritage and Territory of the University of Minho (Lab2PT I UM). Currently, he is a member of MODSCAPES team.

Joaquim Flores. Architect, PhD in architecture (Oxford Brookes University, 2014) and Master Architectural and Urban Rehabilitation. He is professor of the Urbanism area at ESAP. He is also an affiliated researcher at the LIAD - Laboratório de Investigação em Arquitetura e Design and CEAA - Arnaldo Araújo Research Centre (FCT R\&D 4041). Flores 
has been publishing on Architecture, Urban Rehabilitation and Landscape. Currently, he is a member of MODSCAPES team.

Isabel Maria Matias. Architect and Urban planner. PhD (ETSA/University of Valladolid). She is professor of Town Planning, Environmental Planning and Landscape at Lusófona University Porto and is an affiliated researcher at Arnaldo Araújo Research Centre (FCT R\&D unit 4041). Isabel has been developing research on architecture, town planning and landscape. She is cofounder of the Landscape Observatory in Paredes de Coura. Currently, she is member of MODSCAPES - Modernist Reinventions of the Rural Landscape (HERA.15.097).

\section{References}

1. AMARAL, L. 1994. "Portugal e o passado: política agrária, grupos de pressão e evolução da agricultura portuguesa durante o Estado Novo (1950-1973)". Análise Social, vol. 19, $\mathrm{n}^{\circ}$ 128: 889-906. Retrieved from: http://analisesocial.ics.ul.pt/documentos/122337790007jBJ3zI9Px04XU4.pdf [available on 16 January 2019].

2. BAPTISTA, F. O. 1993. A política agrária do Estado Novo, Porto, Edições Afrontamento.

3. FREIRE, D. 2014. "Entre sequeiro e regadio. Políticas públicas e modernização da agricultura em Portugal (século XX)", In XIV Congreso de Historia Agraria (Facultad de Ciencias Económicas y Empresariales, Badajoz: 7-9 November 2013), Badajoz, Universidad Badajoz / SEHA - Sociedad Española de Historia Agraria, p. 1-14. DOI: https://doi.org/10451/17717

4. FREIRE, D. 2011. "Ensayos de ingeniería social: reforma agraria y modernización de la agricultura en las últimas décadas de Estado Novo (1954-1974)". In D. Lañero, D. Freire (eds) Agriculturas e Innovación Tecnológica en la Península Ibérica (1946-1975), Madrid, Ministerio de Medio Ambiente y Rural.

5. JUNTA DE COLONIZAÇÃO INTERNA 1939. Reconhecimento dos baldios do continente - volume I, Lisbon, Junta de Colonização Interna.

6. JUNTA DE COLONIZAÇÃO INTERNA 1941. Plano geral de aproveitamento dos baldios reservados - Volume I, II, Lisbon, Junta de Colonização Interna.

7. JUNTA DE COLONIZAÇÃO INTERNA 1946. Projecto de colonização do Núcleo da Boalhosa, Lisbon, Junta de Colonização Interna.

8. JUNTA DE COLONIZAÇÃO INTERNA 1951. Projecto de Colonização do Núcleo da Boalhosa, Lisbon, Junta de Colonização Interna.

9. GIRÃO, A. 1941. Geografia de Portugal, Porto, Portucalense Editora.

10. LOBO, V.; ANTUNES, A. 1960. Problemas Actuais da Pequena Habitação Rural, Coimbra, Ministério das Obras Públicas. Direcção Geral dos Serviços de Urbanização. Centro de Estudos de Urbanismo.

11. JUNTA DE COLONIZAÇÃO INTERNA 1944. Projecto de colonização dos baldios de Montalegre e Boticas: I Parte - freguesia de Chã, Lisbon, Junta de Colonização Interna: 58.

12. FERNANDES, J. M. 2003. Português suave. Arquitecturas do Estado Novo, Lisbon, Instituto Português do Património Arquitectónico.

13. RAMOS, R. J. G . 2005. "Produções correntes em arquitectura: a porta para uma diferente gramática do projecto do início do século XX", NW noroeste. Revista de 
História, $\mathrm{n}^{\circ}$ 1: 53-80.

14. RAPAZOTE, J. 2012. “'Aldeias-Jardim' no concelho de Montalegre - O projecto da JCI para os baldios do Barroso", GOT - Revista de Geografia e Ordenamento do Território, $\mathrm{n}^{\circ} 1$, Centro de Estudos de Geografia e Ordenamento do Território, p. 207-236. DOI: https://doi.org/10.17127/got/2012.1.010

15. GUERREIRO, F. 2015. Colónias Agrícolas Portuguesas construídas pela Junta de Colonização Interna entre 1936 e 1960. A casa, o assentamento, o território, PhD dissertation, Faculdade de Arquitectura da Universidade do Porto, Porto.

16. CARVALHO JUNIOR, J. 1956. Relatório da actividade desenvolvida na colónia agrícola da Boalhosa (Núcleo de Vascões) no ano de 1955 e plano dos trabalhos a realizar no ano de 1956, Lisbon, Junta de Colonização Interna.

17. AFONSO, M. S.; CAMPELLO, A.; MARTINS, J. B. et al. 1964. Revisão do plano de colonização do Centro da Boalhosa: ano de 1964, Lisbon, Junta de Colonização Interna.

18. JUNTA DE COLONIZAÇÃO INTERNA 1961. Colónia Agrícola da Boalhosa. Estudo Agrológico. Núcleos de Vascões e Lameira do Real, Lisbon, Junta de Colonização Interna.

19. COUNCIL OF EUROPE 2000. European Landscape Convention, Florence, 20.X.2000.

20. BELL, S. 2012. Landscape: pattern, perception and process (2nd Edition), Abingdon, Routledge. DOI: https://doi.org/10.4324/9780203120088

21. CAMARA MUNICIPAL DE PAREDES DE COURA - CMPC 2017. Plano da Paisagem das Terras de Coura, (Relatório de Análise Paisagística. $2^{\mathrm{a}}$ Fase Identificação das Subunidades Paisagísticas), Paredes de Coura, CMPC.

22. DIRECÇÃO-GERAL DO ORDENAMENTO DO TERRITÓRIO E DESENVOLVIMENTO URBANO (DGOTDU) 2011. "A Paisagem na Revisão dos PDM - Orientações para a Implementação da Convenção Europeia da Paisagem no Âmbito Municipal". DGOTDU, Lisbon.

23. DIRECÇÃO-GERAL DO ORDENAMENTO DO TERRITÓRIO E DESENVOLVIMENTO URBANO (DGOTDU) 2004. "Contributos para a Identificação e Caractrização da Paisagem em Portugal Continental”, Volume I, II, III, IV e V, Coleção Estudos 10, DGOTDU, Lisbon.

24. PINTO-CORREIA, T.; CANCELA ABREU, A.; OliVEIRA, R. 2001. "Identificação de unidades de paisagem: Metodologia aplicada a Portugal Continental", Finisterra, vol. 36, n 72: 195-206. DOI: https://doi.org/10.18055/Finis1634

25. DE GROOT, R. 2005. "Functions-analysis and valuation as a tool to assess land use conflicts in planning for sustainable multi-functional landscapes", Landscape and Urban Planning, vol. 75, $\mathrm{n}^{\circ}$ 3-4: 175-186. DOI: https://doi.org/10.1016/j.landurbplan.2005.02.016

26. GREGORY, I. N., \& ELL, P. S. 2007. Historical GIS: technologies, methodologies, and scholarship, New York, Cambridge University Press. DOI: https://doi.org/10.1017/CBO9780511493645

27. ERENA 2008. Plano de Ordenamento e Gestão da Paisagem Protegida de Corno do Bico. $1^{a}$ Fase - Caracterização. Parte 1 Estudos de Base, Lisbon, Instituto de Conservação da Natureza e Biodiversidade. 